\title{
CHEMICAL COMPOSITION AND ANTIMICROBIAL ACTIVITY OF THE ESSENTIAL OIL FROM Aeolanthus suaveolens MART. ex Spreng
}

Euclésio Simionatto*

Departamento de Hidráulica e Transportes, Universidade Federal de Mato Grosso do Sul, 79070-900

Campo Grande - MS, Brasil

Carla Porto, Caroline Z. Stüker, Ionara I. Dalcol e Ubiratan F. da Silva

Departamento de Química, Universidade Federal de Santa Maria, 97105-900 Santa Maria - RS, Brasil

Recebido em 12/12/06; aceito em 18/4/07; publicado na web em 25/9/07

\begin{abstract}
The essential oils from leaves (sample A) and flowers (sample B) of Aeolanthus suaveolens Mart. ex Spreng were obtained by hydrodistillation and analyzed by GC, GC-MS, and chiral phase gas chromatography (CPGC). Six compounds have been identified from the essential oils, representing $\mathrm{ca} 94.3$ and $93 \%$ of the oils corresponding to samples A and B, respectively. The major constituents of samples A and B essential oils were respectively, linalool (34.2\%/34.9\%), (-)-massoialactone (25.9\%/17.0\%) and (E)- $\beta$ farnesene $(25.4 \% / 29.1 \%)$. The enantiomeric distribution of the monoterpene linalool was established by analysis on heptakis(6-O-methyl-2,3-di-O-pentyl)- $\beta$-cyclodextrin capillary column. The antimicrobial activity of the essential oil from leaves and isolated compounds was also evaluated.
\end{abstract}

Keywords: Aeolanthus suaveolens; essential oils; antimicrobial activity.

\section{INTRODUCTION}

The Lamiaceae is one of the most diverse and widespread plant families in terms of ethnomedicine. The medicinal value of Lamiaceae species is largely based on their volatile oils ${ }^{1}$. Regarding its effects on the central nervous system (SNC), studies proved anticonvulsant activities in at least three genera, among which Aeolanthus $^{2}$, Leonurus ${ }^{3}$ and Salvia ${ }^{4}$ are represented in the state of Rio Grande do Sul (RS), Brazil.

Among many essential oils, those from plants within the Lamiaceae family have received considerable attention in the search for biologically active natural products against agricultural as well as stored products pests. In a recent study, was investigated the antifeedant properties of several Lamiaceae essential oils and some of their volatile constituents against onion thrips Thrips tabaci. This raised questions about possible other biological effects of these phytochemicals in the chemical ecology of the onion thrips ${ }^{5-7}$.

Aeolanthus suaveolens Mart. ex Spreng known as "Catinga de Mulata", is a widespread plant in the Northeastern region of Brazil (Brazilian Amazon), and belongs to the Lamiaceae family. It is commonly used in folk medicine because of its sedative and anticonvulsant effects. Earlier reports have demonstrated that this specie presents the monoterpene, linalool, which is the major component of its essential oil and possibly responsible for the plant anticonvulsant properties ${ }^{8,9}$.

In the present work, the chemical composition of the essential oils from leaves and flowers and antimicrobial activity of the essential oil from leaves were further investigated together with some of isolated compounds from essential oil of Aeolanthus suaveolens collected in Rio Grande do Sul. In addition, we report on the enantiomeric distribution of the chiral monoterpene constituent linalool in essential oils of A. suaveolens.

*e-mail: eusimionatto@yahoo.com.br

\section{EXPERIMENTAL}

\section{Plant material}

Aeolanthus suaveolens was collected at the town of São Vicente do Sul, Rio Grande do Sul state, Brazil. Leaves and flowers were collected between November 2003 and September 2004. Voucher specimens (FOET-0504) have been deposited at Herbarium of Federal University of Santa Maria. The leaves of Ocimum basilicum were collected at the town of Santa Maria, RS.

\section{General}

${ }^{1} \mathrm{H}^{-}$and ${ }^{13} \mathrm{C}-\mathrm{NMR}$ spectra were recorded on a Bruker DPX 400 (400.1/100.6 MHz) NMR spectrometer, in $\mathrm{CDCl}_{3}$ with TMS as internal standard. TLC were performed on precoated silica gel 60 F254 plates (Merk) and detection was achieved by UV light (254 $\mathrm{nm}$ ) and by spraying with solutions of $10 \% \mathrm{H}_{2} \mathrm{SO}_{4}$ and $1 \%$ vanillin in ethanol/ $\mathrm{H}_{2} \mathrm{SO}_{4}$, followed by heating.

\section{Chemical analysis}

Fresh leaves and flowers (sample A and B) of Aeolanthus suaveolens and leaves of Ocimum basilicum, were subjected to hydrodistillation for $4 \mathrm{~h}$ using a modified Clevenger-type apparatus, and followed by exhaustive extraction of the distillate with diethyl ether.

The oils were analyzed by GC and GC/MS. GC analyses were performed using a Varian CP-3800 gas chromatograph with a FID detector and SE-54 fused silica column $(25 \mathrm{~m} \mathrm{x} 0.25 \mathrm{~mm}$, film thickness $0.2 \mu \mathrm{m})$. Operation conditions were as follows: injector and detector temperatures, 220 and $280{ }^{\circ} \mathrm{C}$, respectively; carrier gas, $\mathrm{H}_{2}$; oven temperature program from $50-250{ }^{\circ} \mathrm{C}$ at $4{ }^{\circ} \mathrm{C} / \mathrm{min}$. GC-MS analyses were performed using a Varian model 3800 Saturn system operating in the EI mode at $70 \mathrm{eV}$ equipped with a CP-SIL cross-linked capillary column $(30 \mathrm{~m} \times 0.25 \mathrm{~mm}$, film thickness $0.2 \mu \mathrm{m})$. The identity of the oil components was based on comparison 
of the retention times and Kovat's retention indexes and mass spectra with those of NBS/NIST Library and those described by Adams ${ }^{10}$, and by co-injection with standards available in our laboratories.

The enantiomeric distribution of chiral monoterpene linalool in essential oils of $A$. suaveolens and $O$. basilicum was determined by peak enrichment by enantioselective capillary GC with fused capillary column, $25 \mathrm{~m} \times 0.25 \mathrm{~mm}$, coated with heptakis-(6-O-methyl-2,3-diO-pentyl)- $\beta$-cyclodextrin diluted with polysiloxane OV-1701. A Varian3800 apparatus equipped with a flame ionization detector (FID) was used with hydrogen as the carrier gas. All runs were performed with the temperature program from 40 to $180{ }^{\circ} \mathrm{C}$ at $3{ }^{\circ} \mathrm{C} / \mathrm{min}$.

\section{Isolation procedure}

Part of the resulting oils of leaves from Aeolanthus suaveolens $(100 \mathrm{mg})$ was further subjected to preparative TLC $\left(\mathrm{SiO}_{2}\right.$; hexaneEtOAc, 90:15) and afforded massoialactone (16 mg), $\beta$-farnesene $(18 \mathrm{mg}$ ), and linalool (15 mg), respectively (Figure 1). The authenticity of linalool was determined by direct comparison with authentic samples in GC. Massoialactone and $\beta$-farnesene were characterized by GC/MS and NMR data. The absolute configuration of massoialactone $\left[(R)\right.$-isomer $\left.{ }^{11}\right]$ was determined by optical rotation.

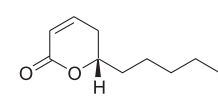

(-) -massoialactone

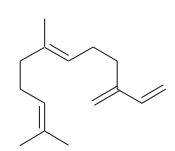

(E)- $\beta$-farnesene

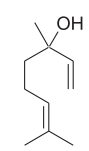

linalool
Figure 1. Structures of the compounds isolated from essential oil of Aeolanthus suaveolens

(-)-massoialactone: $[\alpha]_{\mathrm{D}}$ : -91 (in $\mathrm{CDCl}_{3}, c=0.006$ ); ${ }^{1} \mathrm{H} \mathrm{NMR}$ (400 MHz, $\mathrm{CDCl}_{3}$ ): $\delta 0.82$ (brs, 3H), 1.24-1.93 (m, 8H), 2.23-2.29 (m, 2H), 4.32-4.40 (m, 1H), 5.93-5.97 (m, 1H), 6.78-6.83 (m, 1H); ${ }^{13} \mathrm{C}$ NMR $\left(100 \mathrm{MHz}, \mathrm{CDCl}_{3}\right) \delta 13.9,20.7,24.4,29.4,31.5,34.8$, 78.0, 121.4, 145.0, 164.5.

(E)- $\beta$-farnesene: ${ }^{1} \mathrm{H}$ NMR $\left(400 \mathrm{MHz}, \mathrm{CDCl}_{3}\right): \delta 1.58(\mathrm{~s}, 6 \mathrm{H})$, $1.66(\mathrm{~s}, 3 \mathrm{H}), 1.96-2.23(\mathrm{~m}, 8 \mathrm{H}), 4.97-5.24(\mathrm{~m}, 6 \mathrm{H}), 6.36(\mathrm{dd}, 1 \mathrm{H}$, $\left.J_{1} 10 \mathrm{~Hz}, J_{2} 17 \mathrm{~Hz}\right) .{ }^{13} \mathrm{C} \mathrm{NMR}\left(100 \mathrm{MHz}, \mathrm{CDCl}_{3}\right) \delta 16.0,17.6$, 25.7, 26.6, 26.7, 31.4, 39.7, 113.0, 115.7, 124.0, 124.3, 131.3, 135.4, $139.0,146.1$.

\section{Antimicrobial bioassay}

The antimicrobial activity of sample A was assayed using the Minimal Inhibitory Concentration (MIC). A collection of eleven microorganisms was used, including seven bacteria: Staphylococcus aureus (ATCC 6538p), Staphylococcus epidermidis (ATCC 12228), Bacillus subitilis (ATCC 6633), Klebsiella pneumoniae (ATCC 10031), Eschericchia coli (ATCC 11103), Pseudomonas aeruginosa (ATCC 27873), Salmonella setubal (ATCC 19196); and four yeasts: Candida albicans (ATCC 10231), Saccharomyces cerevisae (ATCC 2601), Cryptococcus neoformans (ATCC 28952) and Candida dublinensis (SM26) (Candida dublinensis was isolated from patients of the University Hospital of Santa Maria). Standard microorganism strains were obtained from American Type Culture Collection (ATCC), and standard antibiotics chloramphenicol and nistatine were used in order to control microbial test sensitivity ${ }^{12}$. The Minimal Inhibitory Concentration (MIC) was determined on 96well culture plates by a micro dilution method using a microorganism suspension with a density of $10^{5} \mathrm{CFU} / \mathrm{mL}$ in Casein Soy Broth (CSB) incubated for $24 \mathrm{~h}$ at $37{ }^{\circ} \mathrm{C}$ for bacteria, and Sabouraud Broth (SB) incubated for $72 \mathrm{~h}$ at $25^{\circ} \mathrm{C}$ for yeasts. The cultures that did not present growth were used to inoculate solid medium plates (Muller Hinton Agar and Sabouraud Agar) in order to determine the Minimal Lethal Concentration (MLC). Proper blanks were assayed simultaneously and samples were tested in triplicate. Technical data was described previously ${ }^{13-15}$.

\section{Bioautographic bioassay}

The antimicrobial activity of isolated compounds (linalool, $\beta$-fanesene and (-)-massoialactone) and crude essential oil (sample A) were assayed using the bioautography technique ${ }^{16-18}$ with a collection of six microorganisms including Staphylococcus aureus, Staphylococcus epidermidis, Bacillus subitilis, Eschericchia coli, Pseudomonas aeruginosa and Salmonella setubal. Compound concentrations from 1.56 to $100 \mu \mathrm{g}$ were applied to precoated TLC plates. Muller Hinton Agar and Sabouraud Agar media inoculated with microorganisms suspended in saline solution $\left(10^{5} \mathrm{CFU} / \mathrm{mL}\right)$ were distributed over TLC plates. Bacterium plates were incubated for $24 \mathrm{~h}$ at $37{ }^{\circ} \mathrm{C}$. Chloramphenicol was used in order to control microbial test sensitivity ${ }^{14}$. The results were stained with an aqueous solution of 2,3,5-triphenyl-tetrazolium chloride (TTC, $1 \mathrm{mg} / \mathrm{mL}$ ). The appearance of inhibition zones was used to determine the lowest sample amount capable of inhibiting microbial growth. Samples were tested in triplicate.

\section{RESULTS AND DISCUSSION}

The content of essential oils from Aeolanthus suaveolens expressed in percentage was as follows: leaves $0.8 \%$ and flowers $0.5 \%$.

The essential oils of Aeolanthus suaveolens obtained from leaves and flowers were analyzed by GC and GC-MS to determine their main constituents. Six compounds were identified, making up $94.3 \%$ of the oil from leaves (Sample A) and $92.6 \%$ of the oil from flowers (Sample B). Table 1 lists the chemical components of the essential oils and differences between sample A and the sample B. The main constituents of the essential oils were linalool $(34.2 \% / 34.9 \%)$, (-)-massoialactone $(25.9 \% / 17.0 \%)$ and $\beta$-farnesene $(25.4 \% / 29.1 \%)$ in samples A and B respectively. Others compounds found in the oils were linalool acetate, $\alpha$-santalene and $\alpha$-bergamotene.

Table 1. Percentage composition of the essential oils of Aeolanthus suaveolens Mart. ex Spreng

\begin{tabular}{lcccc}
\hline Compounds $^{\mathrm{a}}$ & $\begin{array}{c}\text { Leaves } \\
\text { Sample A }\end{array}$ & $\begin{array}{c}\text { Flowers } \\
\text { Sample B }\end{array}$ & RI $^{\mathrm{b}}$ & Identification $^{\mathrm{c}}$ \\
\hline (-)-linalool & 22.5 & 21.6 & 1098 & GC-MS, co \\
(+)-linalool & 12 & 14.3 & 1098 & GC-MS, co \\
linalool acetate & 5.7 & 6.8 & 1255 & GS-MS \\
$\alpha$-santalene & 1.9 & 2.8 & 1418 & GC-MS \\
$\alpha$-bergamotene & 0.9 & 1.4 & 1414 & GC-MS \\
(E)- $\beta$-farnesene & 25.4 & 29.1 & 1458 & NMR, GC-MS \\
(-)-massoialactone & 25.9 & 17.0 & 1476 & NMR, GC-MS \\
TOTAL & 94.3 & 93.0 & & \\
\hline
\end{tabular}

${ }^{\mathrm{a} C o m p o u n d s ~ l i s t e d ~ i n ~ o r d e r ~ o f ~ e l u t i o n ~ f r o m ~ a ~ S E-54 ~ c o l u m n ; ~}{ }^{\mathrm{b}}$ Retention indices determined on apolar SE-54 column $\left(50-250{ }^{\circ} \mathrm{C} ; 4{ }^{\circ} \mathrm{C} \mathrm{min}^{-1}\right)$; 'Identification: RI, GC-MS, gas chromatography-mass spectroscopy; NMR, nuclear magnetic ressonance.

The enantiomeric composition of the chiral monoterpene linalool was investigated, resulting in the detection of an enantiomeric distribution of the (-)-linalool $(22.5 \%) /(+)$-linalool $(12 \%)$ in oil from leaves and (-)-linalool $(21.6 \%) /(+)$-linalool $(14.3 \%)$ in oil from flowers. In accordance with reports in the 
literature ${ }^{19,20}$, the monoterpene linalool can to bear a racemisation process during hydrodistillation. For that reason, was investigated the enantiomeric composition of the linalool in essential oil obtained from Ocimum basilicum (manjericão) (a specie well known by to contain high content of linalool). Through this analysis was observed the enantiomerically pure presence of the isomer (-)-linalool in the essential oil of $O$. basilicum. So that, was concluded that the presence of the enantiomeric mixture of the linalool in the essential of A. suaveolens is natural and not due to an artifact formation.

The antimicrobial activity of the oil from leaves of A. suaveolens was evaluated by determining of the minimal inhibitory concentration (MIC). The results are given in Table 2. The oil was active against all microorganisms tested; being that the best MIC value observed was $1.25 \mathrm{mg} / \mathrm{mL}$ for Escherichia coli and Cryptococcus neoformans. The antimicrobial activity of the essential oil from leaves and isolated compounds (linalool, $\beta$-farnesene and massoialactone) was also tested by bioautography techique. According to results showed in Table 3 was observed that the (-)-massoialactone is the more active component and appear to be the principal responsible for biological properties of the oil. This compound exhibited a more potent antibacterial activity, when compared with others isolated compounds (linalool and $\beta$-farnesene) and crude essential oil. (-)-Massoialactone exhibited antibacterial activity against $S$. setubal $(3.12 \mu \mathrm{g})$, B. subtilis $(3.12 \mu \mathrm{g})$, S. aureus $(6.25 \mu \mathrm{g})$, S. epidermidis $(6.25 \mu \mathrm{g})$, E. coli $(6.25 \mu \mathrm{g})$ and $P$. aeruginosa $(6.25 \mu \mathrm{g})$. The sesquiterpene $\beta$-farnesene showed activity against four microorganisms and the monoterpene linalool was active only against $S$. aureus $(100 \mu \mathrm{g})$. In spite with (-)-massoialactone, this compound has been previously isolated from the bark oil of Critocarya massoia $^{11}$ and jasmine flowers ${ }^{21}$, is also found in the defense secretion of two species of formicin ants of the genus Camponotus ${ }^{22}$.

In conclusion, the present study indicated that the leaf/flower essential oils of Aeolanthus suaveolens possessed a high content of the monoterpenes $(66.1 \% / 59.7 \%)$ and sesquiterpene $(28.2 \% / 33.3 \%)$, respectively. Linalool, $\beta$-farnesene and (-)-massoialactone were the isolated substances that are presented in the essential oils. The antimicrobial activity of these compounds was evaluated by bioautography technique, which showed the remarkable antimicrobial
Table 2. Antimicrobial activity of the essential oil from leaves of the Aeolanthus suaveolens (minimal inhibitory concentration (MIC) and the minimal letal concentration (MLC) in $\mathrm{mg} \mathrm{mL}^{-1}$ )

\begin{tabular}{|c|c|c|c|}
\hline \multirow[t]{2}{*}{ Microorganisms } & \multicolumn{2}{|c|}{$\begin{array}{c}\text { Leaves } \\
\text { Sample A }\end{array}$} & \multirow{2}{*}{$\begin{array}{c}\text { Standard }^{\mathrm{a}, \mathrm{b}} \\
\text { CIM }\end{array}$} \\
\hline & $\mathrm{CIM}^{\mathrm{a}}$ & $\mathrm{CLM}^{\mathrm{a}}$ & \\
\hline Staphylococcus aureus & 10 & $>20$ & $6.25 \times 10^{-3}$ \\
\hline Staphylococcus epidermidis & 10 & $>20$ & $3.12 \times 10^{-3}$ \\
\hline Escherichia coli & 1.25 & 5 & $1.67 \times 10^{-3}$ \\
\hline Pseudomonas aeruginosa & 5 & $>20$ & $3.12 \times 10^{-3}$ \\
\hline Klebsiella pneumoniae & 10 & $>20$ & $6.25 \times 10^{-3}$ \\
\hline Bacillus subtilis & 10 & $>20$ & $3.12 \times 10^{-3}$ \\
\hline Salmonella setubal & 10 & $>20$ & $1.67 \times 10^{-3}$ \\
\hline Cryptococcus neoformans & 1.25 & 2.5 & $4.06 \times 10^{-3}$ \\
\hline Saccharomyces cereviseae & 2.5 & 5 & $8.12 \times 10^{-3}$ \\
\hline Candida albicans & 5 & 10 & $8.12 \times 10^{-3}$ \\
\hline Candida dublinensis & 2.5 & 10 & $8.12 \times 10^{-3}$ \\
\hline
\end{tabular}

${ }^{\mathrm{a}}$ Mean of 3 replicates in $\mathrm{mg} \mathrm{mL}{ }^{-1}$. ${ }^{\mathrm{b}}$ Standard antimicrobial agents: chloramphenicol against bacteria and nistatine against yeasts.

potential of the (-)-massoialactone. The crude essential oil from $A$. suaveolens also exhibited a good antimicrobial activity.

According the found results, it can be concluded that the essential oil of Aeolanthus suaveolens, from leaves and flowers, are similar in terms of the chemical composition. The presence of an enantiomerically mixture of the linalool in essential oil of A. suaveolens is a natural occurrence, and is not due to an artifact formation during hydrodistillation process. The component (-)-massoialactone appear to be the main responsible for the biological properties of the oil.

\section{ACKNOWLEDGEMENTS}

This work was supported by SCT (Secretaria de Ciência e Tecnologia do Estado do Rio Grande do Sul), CAPES (Coordenação de Aperfeiçoamento de Pessoal de Nível Superior) and CNPq (Conselho Nacional de Desenvolvimento Científico e Tecnológico).

Table 3. Antimicrobial activity: minimum amount required, for essential oil and isolated compounds, for inhibition of bacterial growth on TLC plates $(\mu \mathrm{g})$

\begin{tabular}{lccccc}
\hline Microorganisms & Essential oil (leaves) & $(E)-\beta$-farnesene & linalool & massoialactone $^{\text {Standard }^{\text {a }}}$ \\
\hline S. aureus & 50 & 50 & 100 & 6.25 & 6.25 \\
S. epidermidis & - & - & - & 6.25 & 0.7 \\
E. coli & 50 & - & - & 3.125 & 0.4 \\
S. setubal & 50 & 100 & - & 0.25 & 0.6 \\
P. aeruginosa & 50 & 12.5 & - & 3.125 \\
B. subtilis & 25 & &
\end{tabular}

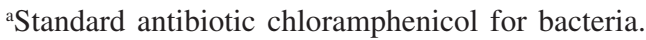

\section{REFERENCES}

1. Moerman, D. E.; J. Ethnopharmacol. 1991, 31, 1.

2. Elisabetsky, E.; Coelho de Souza, G. P.; Siqueira, I. R.; Amador, T. A.; Correa, M. A.; Fitoterapia 1995, 66, 407.

3. Chauan, A. K.; Dobhal, M. P.; Joshi, B.; J. Ethnopharmacol. 1988, 22, 1.

4. González, A. G.; Luis, J. G.; Ravelo, A. G.; Em Plantas iberoamericanas. Fuentes de moléculas bioactivas II. Lamiaceae; Herrera, J. R.; Rodriguez, C. M.; San Andrés, L.; Navarro, A. G.; Moujir, L., eds.; Litografia Romero: Tenerife, 1990.

5. Koschier, E. H.; Sedy, K. A.; Crop Prot. 2003, 22, 929.

6. Mansour, F.; Ravid, U.; Putievsky, E.; Phytoparasitica 1986, 14, 137.

7. Calmasur, O.; Aslan, I.; Sahin, F.; Ind. Crop. Prod. 2006, 23, 140.

8. Elisabetsky, E.; Marschner, J.; Souza, D. O.; Neurochem. Res. 1995, 20, 461.

9. Elisabetsky, E.; Brum, L. F.; Souza D. O.; Phytomedicine 1999, 6, 107.

10. Adams, R. P.; Identification of essential oil components by gas chromatographic mass spectroscopy, Allured Publishing Co, Carol Steam: Illinois, 1995.
11. Mori, K.; Agri. Biol. Chem. 1976, 40, 1617.

12. Food and Drugs Administration; Code of Federal Regulations 1991, 21, 300.

13. Hammer, K. A.; Carson, C. F.; Riley, T. V.; J. Appl. Microbiol. 1999, 86, 985.

14. National Committee for Clinical Laboratory Standards; Reference method of broth dilution antifungal susceptibility testing of yeasts, Standard M77T, NCCLS 1995, Villanova.

15. National committee for Clinical Laboratory Standards; Methods for Dilution. Antimicrobial Susceptibility Tests for Bacteria that grow aerobically (Standard M7-A2), NCCLS 1985, Villanova.

16. Homans, A. L.; Fuchs, A.; J. Chromatogr., A 1970, 51, 327.

17. Hamburger, M. O.; Cordell, A. G.; J. Nat. Prod. 1987, 50, 19.

18. Rahalison, L.; Hamburger, M.; Hostettmann, K.; Monod, M.; Frenk, E.; Phytochem. Anal. 1991, 2, 199.

19. Bicchi, C.; D'Amato, A.; Rubiolo, P.; J. Chromatogr., A 1999, 843, 99.

20. Marriott, P. J.; Shellie, R.; Cornwel, C.; J. Chromatogr., A 2001, 936, 1

21. Kaiser, R.; Lamparsky, D.; Tetrahedron Lett., 1976, 1659.

22. Cavill, G. W. K.; Clark, D. V.; Whitefield, F. B.; Aust. J. Chem. 1968, 21, 2819. 